\title{
Hyperbilirubinemia impact on newborn hearing: a literature review
}

\author{
Marcela Hammes Teixeira' \\ DViviann Magalhães Silva Borges ${ }^{1}$ \\ (iD) Rudimar dos Santos Riesgo ${ }^{2}$ \\ (iD) Pricila Sleifer ${ }^{\mathbf{1}}$
}

1. Departamento de Saúde e Comunicação Humana da Universidade Federal do Rio Grande do Sul, Porto Alegre, RS, Brasil. 2. Departamento de Pediatria da Universidade Federal do Rio Grande do Sul, Porto Alegre, RS, Brasil.

http://dx.doi.org/10.1590/1806-9282.66.7.1002

\begin{abstract}
SUMMARY
The increase in bilirubin levels in newborns can cause toxic effects on the auditory system, which can lead to hearing loss. This review aimed to verify the impact of hyperbilirubinemia in the hearing of newborns, relating audiological findings to serum levels of bilirubin. $A$ literature review was conducted during October 2017, using the terms "hyperbilirubinemia", "jaundice", "infant", "newborn" and "hearing loss", on databases CAPES journals, MEDLINE and BIREME (SCiELO, BBO). 827 studies were identified and 59 were selected for fulltext reading, resulting in the selection of seven articles that met the inclusion criteria and were considered relevant to the sample of this study. All the reviewed studies performed brainstem auditory evoked potential as the main test for audiological evaluation. Changes in the audiological findings of neonates with hyperbilirubinemia were observed in all studies. There was no consensus on the serum bilirubin levels that may cause auditory changes; however, the relationship between hearing disorders and blood levels of bilirubin was positive. We identify the need to establish reference values for bilirubin levels considered critical for the occurrence of hearing disorders as well as the audiological follow-up of neonates with hyperbilirubinemia.
\end{abstract}

KEYWORDS: Hyperbilirubinemia. Infant, newborn. Jaundice. Hearing loss.

\section{INTRODUCTION}

Neonatal hyperbilirubinemia affects approximately half of all newborns (NB) born at full term and 80\% of pre-term infants during the first week of life ${ }^{1.2}$. The increase in the levels of bilirubin is usually mild, transient, and not harmful to the neonates'. However, since it is liposoluble, high levels of bilirubin can cross the blood-brain barrier and cause damage to the central nervous system (CNS) ${ }^{3.4}$. High serum bilirubin levels also have a toxic effect on the auditory system, although many of these damages are revers$i_{b l e}$. Studies indicate that the auditory nuclei in the brainstem, the inferior colliculus, and the superior olivary complex are particularly more susceptible to the effects of bilirubin, and lesions in these structures may lead to sensorineural hearing loss ${ }^{4.6}$.

The Auditory Brainstem Response (ABR) is the most sensitive measurement to assess retrocochlear lesions, as well as the integrity of the auditory pathway. However, the use of this measurement in cases of neonatal hyperbilirubinemia is quite controversial, since the relationship between the serum levels of bilirubin and auditory alterations is not well defined ${ }^{4,6,7}$. Some studies suggest abnormalities in the ABR when there is an increase of bilirubin levels, while others

DATE OF SUBMISSION: 09-Oct-2019

DATE OF ACCEPTANCE: 23-Feb-2020

CORRESPONDING AUTHOR: Pricila Sleifer

Departamento Saúde e Comunicação Humana da UFRGS - Núcleo de Estudos em Eletrofisiologia da Audição

Ramiro Barcelos, 2600, térreo, Santa Cecília, Porto Alegre, RS, Brasil - 90035-003

Tel: +55 513308-5066

E-mail: pricilasleifer@gmail.com 
do not report the same findings ${ }^{7}$. In the same way, the thresholds of blood bilirubin considered critical to the development of auditory changes have not been determined. Some authors suggest that levels above $20 \mathrm{mg} / \mathrm{dL}$ may cause sensorineural hearing loss ${ }^{1,5,7,8}$, while others consider severe hyperbilirubinemia when the levels of serum bilirubin reach $17 \mathrm{mg} / \mathrm{dL}^{4}$. Auditory alterations have also been described in preterm newborns with levels of serum bilirubin levels below the thresholds set for exchange transfusion? ${ }^{9}$.

Thus, the objective of this systematic literature review was to evaluate the impacts of hyperbilirubinemia in newborn hearing, correlating the audiological findings to serum bilirubin levels.

\section{METHODS}

Bibliographical research was carried out in October 2017 on the Latin American and Caribbean Health Sciences Literature (Lilacs), Medical Literature Analysis and Retrieval System Online (MEDLINE), and the Coordination for the Improvement of Higher Education Personnel Journal Portal (Capes) electronic databases. We searched for papers published by September 2015, without limitation of the initial date. The search strategy applied followed recommendations of the Cochrane Handbook for Systematic Reviews of interventions ${ }^{10}$. All terms used in the search are terms indexed in the Health Sciences Descriptors (DeCS) vocabulary, and the search for the review was conducted in the databases using all possible combinations between the terms hyperbilirubinemia, jaundice, infant, newly-birth and hearing loss, using the AND operator.

For the selection and evaluation of the studies retrieved, the following inclusion criteria were established: original studies involving full-term and preterm newborns with hyperbilirubinemia confirmed by laboratory exams, submitted to at least one clinical Auditory Brainstem Response evaluation (ABR) and/ or evoked otoacoustic emissions (OAE), published in Portuguese, English, and Spanish. We excluded from the analysis studies performed on animals, studies in which hyperbilirubinemia was not the only one risk factor for hearing loss, studies that used other audiological examinations, literature reviews, letters to the editor, and case studies. The methodology followed the recommendations of the Oxford Center for Evidence-Based Medicine ${ }^{11}$, using studies up to level 3 due to their scientific impact.
After analyzing the abstracts and titles of the studies found in the initial search, 59 were selected for the reading of the full texts. Of these, we excluded those that did not meet the inclusion criteria, after which nine studies remained.

The nine studies selected were analyzed using the Critical Appraisal Skills Programme (CASP) ${ }^{12}$ instrument, after which two were excluded, one for not presenting a statistical analysis of the data and the other due to inconsistencies in the sample selection.

The process of selection of articles is described in Figure 1.

The analysis of the studies selected considered the author and year of publication, type and design of the study, sample characterization (number, gender, and mean age), audiological procedures used, the period of auditory assessment, bilirubin levels, in addition to the results and conclusions obtained.

\section{RESULTS}

The seven papers selected were published between 1990 and 2017. As for the country of origin, three were from India ${ }^{13-15}$, one from Mexico ${ }^{16}$, one from Iran $^{3}$, one from Singapore ${ }^{17}$ and one from Brasil ${ }^{18}$. Of these, only

\section{FIGURE 1}

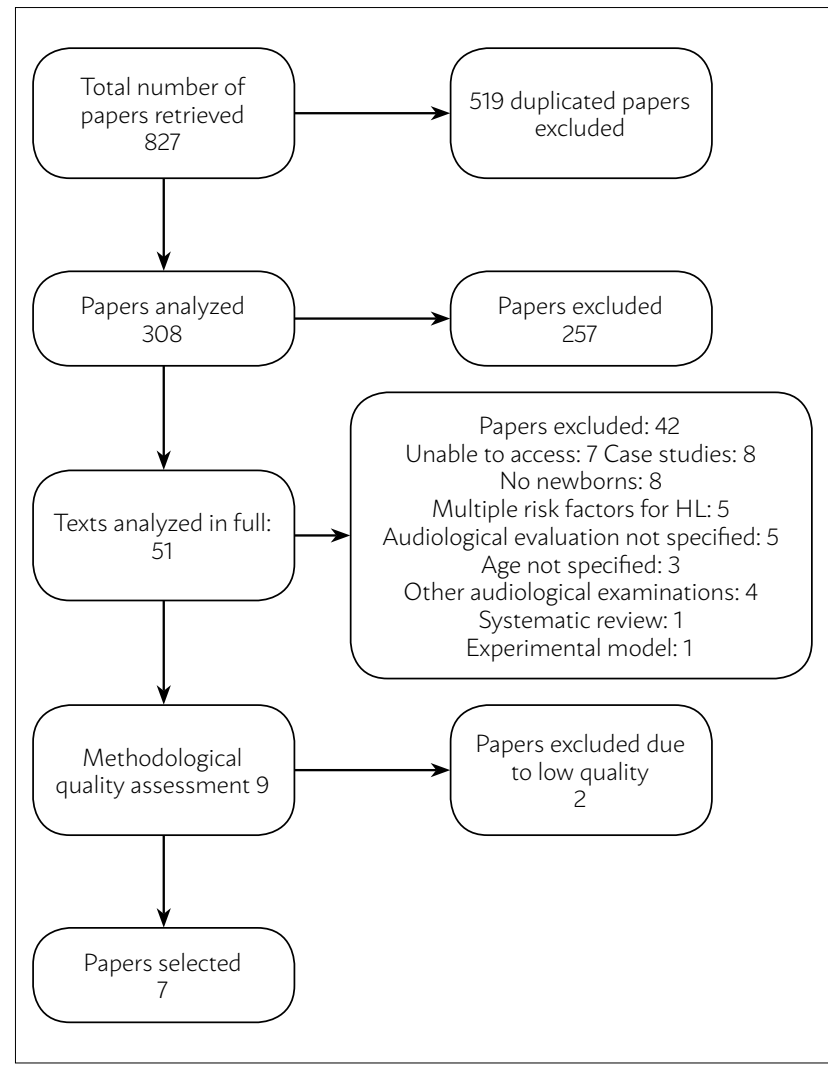


one $^{16}$ was published in Spanish, while the others were published in English.

The sample sizes varied from 25 to 71 neonates (average of 39.7 subjects per study), with a predominance of male infants in $80 \%$ of the studies in which this data was specified ${ }^{3,13,15,16}$.

In all the studies analyzed, the ABR was the main audiological examination performed, and only one study the Otoacoustic Emissions (OAE) were also used $^{16}$. As for the period in which the audiological examination was performed, the data found were quite distinct. In two studies, the assessment was carried out at the time of hospital discharge, when the bilirubin levels were already normalized ${ }^{3.15}$, but in only one of them, there was an indication to retest at three and six months if the outcome of the first evaluation was abnormal ${ }^{15}$. One study carried out an audiological follow-up along with the phototherapy treatment ${ }^{17}$. Another study performed the audiological evaluation on the day of the highest peak of serum bilirubin ${ }^{18}$. In both surveys, the ABR was performed before and after the treatment of hyperbilirubinemia ${ }^{13.14}$, and in one of these there was also a follow-up, with auditory evaluations of the infants at 14 weeks and again at 1 year of age ${ }^{13}$. Only one study did not explicitly mention when the audiological evaluation was performed, stating that it was not possible to test all neonates before the treatment, which allowed us to infer that the tests were performed after the treatment ${ }^{16}$.

Alterations were observed in the ABR evaluation of newborns with hyperbilirubinemia in all studies reviewed. With regard to their absolute latencies and interpeak intervals, $71 \%$ of the studies reported increased wave $V$ latency and increased interpeak $\mathrm{I}-\mathrm{V}$ interval in the groups of children with hyperbilirubinemia in comparison to the groups without hyperbilirubinemia ${ }^{3,13,15,17,18}$. These data are detailed in Figure 2. Only one study reported a reduction of wave III absolute latency and amplitude which were justified as an isolated event due to a reduction in the auditory propagation ${ }^{16}$. In this study, abnormalities in the ABR were observed only in cases in which the bilirubin levels were above $28 \mathrm{mg} / \mathrm{dL}$.

FIGURE 2

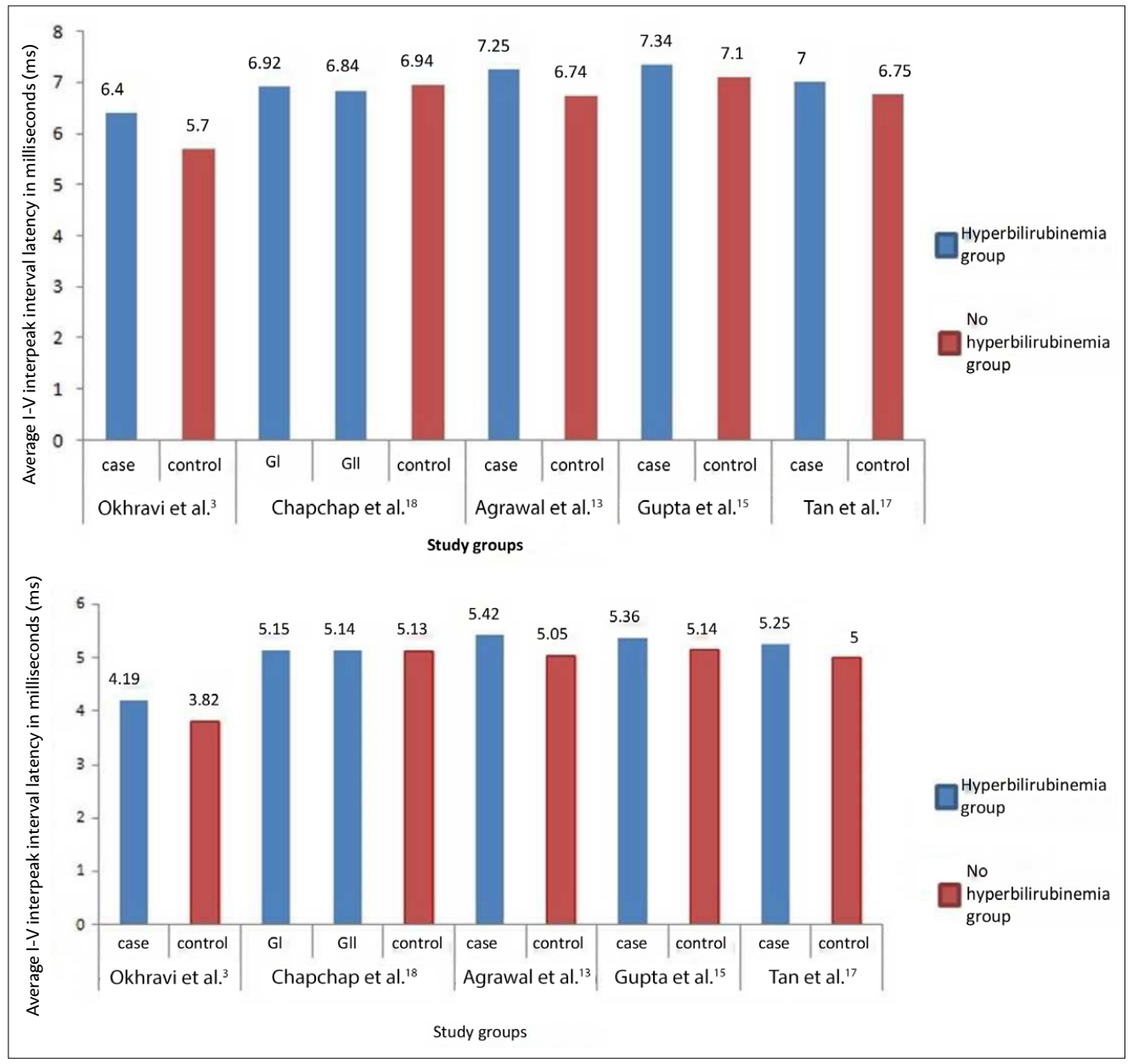


In total, four studies conducted auditory evaluations pre- and post-treatment ${ }^{13-15,17}$. In only one the reduction of absolute latencies and interpeak intervals after the treatment was not statistically significant ${ }^{14}$. In three, it was possible to observe reductions in the absolute latencies and interpeak intervals after the reduction of the bilirubin levels ${ }^{13,15,17}$, and in one ${ }^{13}$, the authors reported that of the 15 neonates with ABR abnormalities before the treatment, in only three the abnormalities remained when retested at 14 weeks.

The relationship between the audiological alterations and bilirubin levels was statistically significant in five of the studies reviewed ${ }^{3,13,15,17}$. In cases in which the auditory evaluation was performed before and after the treatment, the reduction or absence of abnormalities in the ABR followed the decline of the bilirubin levels ${ }^{13,15,17}$. In one study, a weak positive association was observed between the levels of indirect bilirubin and the $\mathrm{ABR}^{18}$. This association was found only when the two groups of neonates with jaundice were analyzed as a whole, in comparison to the control group. In two other studies, no correlation between the levels of bilirubin and abnormalities in the ABR was found ${ }^{14.16}$.

In this review, two studies reported the use of serum bilirubin as a marker.15: one used total bilirubin $^{13}$ and two indirect bilirubin ${ }^{16.18}$. Only one study used direct bilirubin ${ }^{17}$, while one did not mention the method used for bilirubin measurement ${ }^{14}$.

In most studies $(\mathrm{n}=4)$, the cause for hyperbilirubinemia was idiopathic, i.e., physiological changes in the bilirubin levels became pathological due to unknown causes ${ }^{3,14,16,18}$. These same studies reported the percentage of cases due to incompatibilities of the $\mathrm{ABO}$ system (blood types A, B, AB, and O) or of Rh (Rhesus) factor. The other studies did not report the causes $^{13,15,17}$.

In Table 1, we present the seven studies selected and their main characteristics.

\section{DISCUSSION}

In all studies, the ABR was used in the assessment of newborns. Considering that the toxicity of bilirubin affects the auditory nuclei in the brainstem, the use of evoked potentials seems to be more effective in detecting retrocochlear alterations ${ }^{1,4,7}$. In addition, other studies have demonstrated that the OAE alone is not adequate for auditory evaluation in cases of hyperbilirubinemia ${ }^{5.19}$. Still, according to other studies, auditory neuropathy, often caused by hyperbilirubinemia, is defined by alterations or the absence of waves on the ABR, while OAE remains present ${ }^{1}$. These data indicate the need to associate both examinations for a more comprehensive audiological evaluation ${ }^{5.19}$.

The studies presented differences regarding the time chosen for evaluation. In general, we observe that there is no standardization for the auditory evaluation of newborns with hyperbilirubinemia, and it is more common to carry out examinations when the bilirubin levels are within the normal range, at the time of hospital discharge. In Brasil, the Ministry of Health drew up the Attention Guidelines for Neonatal Hearing Screening to guide children's hearing health care, determining that hyperbilirubinemia is a risk factor for hearing loss and, therefore, requires following a specific flow for hearing monitoring. In relation to these guidelines, newborns with risk indicators for hearing loss should undergo screening within the first 30 days of life, preferably using the ABR and, even when the results are satisfactory, babies need undergo audiological follow-up at 7 and 12 months ${ }^{20}$.

In addition, it is important to highlight that in all studies alterations were observed in the ABR evaluation in this population, and most of the studies reported increased wave $\mathrm{V}$ latency and increased interpeak I-V interval ${ }^{3,13-15,17}$, which is similar to findings of other studies with a comparable population ${ }^{5,7,19}$. These changes suggest that the neural conduction in the brainstem is changed by the neurotoxic effects of bilirubin ${ }^{1}$. The audiological findings of each study are shown in Table 1.

Some researchers argue that the auditory changes resulting from the toxicity of bilirubin in the CNS are reversible before the first two years of life $\mathrm{e}^{5}$. In another study, it was observed that abnormalities in the ABR may remain even after the treatment with phototherapy/exchange transfusion, indicating the need for audiological follow-up to identify whether these changes are really transient or if it is a case of auditory neuropathy induced by the bilirubin levels ${ }^{3}$.

There was a statistically significant correlation between the audiological changes and the bilirubin levels in most of the studies included in the review ${ }^{3,13,15,17}$. However, the literature has been quite controversial as to this direct relationship between changes in the ABR and the bilirubin levels. Some studies have shown that this relationship between audiological changes and hyperbilirubinemia exists ${ }^{1,5,8}$, contradicting the results of other studies that report that this correlation could 
TABLE 1. DATA EXTRACTED FROM THE STUDIES SELECTED.

\begin{tabular}{|c|c|c|c|c|c|c|}
\hline $\begin{array}{l}\text { Author } \\
\text { and year }\end{array}$ & $\begin{array}{l}\text { Study } \\
\text { design }\end{array}$ & $\begin{array}{l}\text { Population studied and } \\
\text { bilirubin levels }\end{array}$ & $\begin{array}{l}\text { Exams } \\
\text { Carried } \\
\text { out }\end{array}$ & $\begin{array}{l}\text { Time of the auditory } \\
\text { evaluation }\end{array}$ & Objective of the study & Audiological results \\
\hline $\begin{array}{l}\text { Okhravi } \\
\text { et al. }{ }^{3} \\
\text { (2015) }\end{array}$ & $\begin{array}{l}\text { Case- } \\
\text { control }\end{array}$ & $\begin{array}{l}\text { Full term and pre-term } \\
\text { NB with serum bilirubin } \\
\geq 18 \mathrm{mg} / \mathrm{dL} \text {. }\end{array}$ & $A B R$ & At hospital discharge. & $\begin{array}{l}\text { Compare the } A B R \text { results } \\
\text { of NB with and without } \\
\text { hyperbilirubinemia. }\end{array}$ & $\begin{array}{l}\text { Increase of absolute waves } \\
\text { I, III, and } V \text { latencies and } \\
\text { of interpeak intervals (I-V, } \\
\text { I-III and III-V) at hospital } \\
\text { discharge. }\end{array}$ \\
\hline $\begin{array}{l}\text { Chapchap } \\
\text { et al. }{ }^{\mathbf{1 8}} \\
(2006)\end{array}$ & $\begin{array}{l}\text { Case- } \\
\text { control }\end{array}$ & $\begin{array}{l}\text { Full-term NB with hyper- } \\
\text { bilirubinemia } \\
\text { Gl: severe physiological } \\
\text { jaundice. } \\
\text { Gll: hemolytic jaundice. }\end{array}$ & $A B R$ & $\begin{array}{l}\text { On the day of the } \\
\text { highest peak of } \\
\text { serum bilirubin. }\end{array}$ & $\begin{array}{l}\text { Evaluate the conduction } \\
\text { of stimulus in the audi- } \\
\text { tory pathway, comparing } \\
\text { the responses between } \\
\text { the two groups evaluated. }\end{array}$ & $\begin{array}{l}\text { Increase of the absolute } \\
\text { latency of wave I and of } \\
\text { interpeak III-V interval }\end{array}$ \\
\hline $\begin{array}{l}\text { Martiñón } \\
\text { et al. }{ }^{16} \\
(2000)\end{array}$ & $\begin{array}{l}\text { Case- } \\
\text { control }\end{array}$ & $\begin{array}{l}\text { Full-term NB with differ- } \\
\text { ent levels of bilirubin } \\
\text { Gl: } 12-20.9 \mathrm{mg} / \mathrm{dL} \\
\text { Gll: } 21-24.9 \mathrm{mg} / \mathrm{dL} \\
\text { GlII: } 25-27.9 \mathrm{mg} / \mathrm{dL} \\
\text { GIV: } \geq 28 \mathrm{~g} / \mathrm{dL}\end{array}$ & $\begin{array}{l}\mathrm{EOA} \text { and } \\
\mathrm{ABR}\end{array}$ & $\begin{array}{l}\text { After the treatment } \\
\text { (phototherapy and/or } \\
\text { exchange transfusion) }\end{array}$ & $\begin{array}{l}\text { Evaluate and compare } \\
\text { the responses obtained } \\
\text { from the four groups } \\
\text { studied. }\end{array}$ & $\begin{array}{l}\text { Adequate absolute latency } \\
\text { of waves I and } V \text {, and } \\
\text { reduction of the absolute } \\
\text { latency and amplitude of } \\
\text { wave III. }\end{array}$ \\
\hline $\begin{array}{l}\text { Agrawal } \\
\text { et al. }{ }^{13} \\
(1998)\end{array}$ & $\begin{array}{l}\text { Case- } \\
\text { control }\end{array}$ & $\begin{array}{l}\text { Full-term NB with differ- } \\
\text { ent levels of bilirubin } \\
\text { GA: } 15-20 \mathrm{mg} / \mathrm{dL} \\
\text { GB: } 21-25 \mathrm{mg} / \mathrm{dL} \\
\text { GC: }>25 \mathrm{mg} / \mathrm{dL}\end{array}$ & ABR & $\begin{array}{l}\text { Before the treatment } \\
\text { (phototherapy/ex- } \\
\text { change transfusion); } \\
\text { when bilirubin levels } \\
<12 \text { mg/dL; } 14 \text { weeks; } \\
1 \text { year. }\end{array}$ & $\begin{array}{l}\text { Compare the findings } \\
\text { obtained on the ABR } \\
\text { between the groups, as } \\
\text { well as before and after } \\
\text { the treatment. }\end{array}$ & $\begin{array}{l}\text { Increase of absolute latency } \\
\text { of waves I, III, and } V \text { and of } \\
\text { interpeak intervals (I-III and } \\
\text { III-V). Reduction of these } \\
\text { after the treatment. }\end{array}$ \\
\hline $\begin{array}{l}\text { Bhandari } \\
\text { et al. }{ }^{\mathbf{1 4}} \\
(1993)\end{array}$ & $\begin{array}{l}\text { Longi- } \\
\text { tudinal }\end{array}$ & $\begin{array}{l}\text { Full-term NB with plas- } \\
\text { ma bilirubin } \geq 15 \mathrm{mg} / \mathrm{dL}\end{array}$ & $\mathrm{ABR}$ & $\begin{array}{l}24 \mathrm{~h} \text { after the } \\
\text { hyperbilirubinemia } \\
\text { diagnosis and after } \\
\text { the treatment, when } \\
\text { bilirubin } \leq 10 \mathrm{mg} / \mathrm{dL}\end{array}$ & $\begin{array}{l}\text { Study the effect of hyper- } \\
\text { bilirubinemia in } A B R \text { and } \\
\text { analyze the responses } \\
\text { obtained on the ABR } \\
\text { after the treatment. }\end{array}$ & $\begin{array}{l}\text { Increase of absolute laten- } \\
\text { cies of waves I, III, and V } \\
\text { and of interpeak intervals } \\
(I-V, I-I I I \text {, and III-V) before } \\
\text { the treatment and their re- } \\
\text { duction after the treatment. }\end{array}$ \\
\hline $\begin{array}{l}\text { Tan } \\
\text { et al. } \\
(1992)\end{array}$ & $\begin{array}{l}\text { Case- } \\
\text { control }\end{array}$ & $\begin{array}{l}\text { Full-term NB with a } \\
\text { diagnosis of hyperbiliru- } \\
\text { binemia. }\end{array}$ & ABR & $\begin{array}{l}\text { Before phototherapy; } \\
24 \text { h after photother- } \\
\text { apy; after photother- } \\
\text { apy; one day after the } \\
\text { end of phototherapy. }\end{array}$ & $\begin{array}{l}\text { Evaluate how the } \\
\text { reduction of bilirubin } \\
\text { levels from phototherapy } \\
\text { affects the ABR. }\end{array}$ & $\begin{array}{l}\text { Increase of the absolute } \\
\text { latency of wave } V \text { and of in- } \\
\text { terpeak I-V and III-V. After } \\
\text { phototherapy, the values } \\
\text { were close to normal. }\end{array}$ \\
\hline $\begin{array}{l}\text { Gupta } \\
\text { et al. } \\
(1990)\end{array}$ & $\begin{array}{l}\text { Case- } \\
\text { control }\end{array}$ & $\begin{array}{l}\text { Full-term NB with serum } \\
\text { bilirubin } \geq 20 \mathrm{mg} / \mathrm{dL} \text {. }\end{array}$ & $\mathrm{ABR}$ & $\begin{array}{l}\text { At hospital discharge. } \\
\text { RN who failed this } \\
\text { test were reassessed } \\
\text { at } 3 \text { and } 6 \mathrm{~m} \text {. }\end{array}$ & $\begin{array}{l}\text { Evaluate abnormalities } \\
\text { in the ABR in newborns } \\
\text { with hyperbilirubinemia } \\
\text { who underwent exchange } \\
\text { transfusion compared to } \\
\text { NB without jaundice. }\end{array}$ & $\begin{array}{l}\text { Increase of the absolute } \\
\text { latency of waves III and } \\
V \text { and of the interpeak } \\
\text { intervals I-V. The latencies } \\
\text { decreased at the retest after } \\
3 \text { months. }\end{array}$ \\
\hline
\end{tabular}

NB: newborn; G: group, ABR: Evoked auditory brainstem response; OAE: distortion-product otoacoustic emissions; mg/dL: milligrams per deciliter

not be established ${ }^{4,9,21}$. In many cases, the absence of correlation is justified by differences in the bilirubin levels defined as critical to the start of treatment, as well as the type of bilirubin used in the examinations.

The studies presented differences regarding the type of bilirubin used as a marker of the levels of the substance in the blood. In addition, there is no standard value defined as critical for hyperbilirubinemia. In the studies reviewed, the values ranged from 12 to $35 \mathrm{mg} / \mathrm{dL}$. The Joint Committee on Infant Hearing $(\mathrm{JCIH})^{22}$ has also not defined values, just refers as risk factors for hearing loss the hyperbilirubinemia cases in which in the serum levels of total bilirubin require exchange transfusion ${ }^{2,21,22}$. The most widely used value as an indicator of the need for treatment is total bilirubin $>20 \mathrm{mg} / \mathrm{dL}^{1}$. However, other studies have reported changes in the ABR results of preterm neonates who have not reached the thresholds of bilirubin considered critical for exchange transfusion ${ }^{2.9}$. These data indicate the need for standardization of the values and type of bilirubin used as a reference for risk of hearing loss induced by bilirubin, differentiating them especially according to the presence of prematurity, in addition to using them as reference for treatment referral.

Another point to be discussed is the etiology of hyperbilirubinemia which, according to the studies analyzed, is multifactorial. The matter is that in cases in which hyperbilirubinemia is caused due to incompatibilities of the $\mathrm{ABO}$ or Rh systems, there is an increase in the rate of hemolysis; therefore, the bilirubin levels may be higher than in other pathological conditions $^{21}$. One study made a distinction between these two groups, showing that the bilirubin levels were lower in the group with aggravated physiological jaundice, although there was no distinction in the ABR results between the groups, only when they were 
compared together against the control group ${ }^{18}$. These data confirm the need for standardization of bilirubin values in different situations, so as to achieve an early diagnosis of hearing loss, as well as for audiological follow-up in cases of remission.

\section{CONCLUSION}

The relationship between audiological changes and blood levels of bilirubin, though sometimes controversial, proved to be positive. Using the ABR as the clinical examination of choice for assessing the newborns, we found that in hyperbilirubinemia cases, changes occur in the absolute latencies and interpeak intervals, suggesting a loss of neural conduction in the brainstem, possibly caused by the toxicity of bilirubin, which can be the cause of sensorineural hearing loss.
In addition, it was possible to note the need to establish reference values for the bilirubin levels considered critical for audiological abnormalities, as well as to carry out audiological follow-up of newborns with hyperbilirubinemia, particularly of preterm infants.

\section{Author's Contribution}

MHT chose the descriptors, analyzed the studies included and excluded, was responsible for the scientific writing of the study; VMSB aided in the scientific writing of the study and provided intellectual contribution; RSR offered guiding and intellectual contributions; PS offered guiding, chose the descriptors, analyzed the studies included and excluded, was responsible for the scientific writing of the study and provided intellectual contributions.

\section{RESUMO}

O aumento nos níveis de bilirrubina no neonato pode provocar efeitos tóxicos no sistema auditivo, podendo levar à perda auditiva. O objetivo desta revisão foi verificar o impacto da hiperbilirrubinemia na audição de recém-nascidos, relacionando os achados audiológicos aos níveis séricos de bilirrubina. Realizou-se uma revisão sistemática de literatura durante o mês de outubro de 2017, utilizando-se os termos hyperbilirubinemia, jaundice, infant, newborn e hearing loss, nas bases de dados periódicos Capes, Medline e Bireme (SciELO, BBO). Foram identificados 827 estudos, dentre os quais 59 foram selecionados para leitura do texto na íntegra, resultando na seleção de sete artigos que atendiam aos critérios de inclusão e foram considerados relevantes para a amostra deste trabalho. Em todas as pesquisas revisadas, o potencial evocado auditivo de tronco encefálico foi o principal exame audiológico realizado. Em todos os estudos foram observadas alterações nos resultados audiológicos de neonatos com hiperbilirrubinemia. Não houve consenso quanto aos níveis séricos de bilirrubina que podem causar alterações auditivas, porém, a relação entre as alterações audiológicas e os níveis sanguíneos de bilirrubina foi positiva. Percebeu-se a necessidade de estabelecer valores de referência para os níveis de bilirrubina considerados críticos para a ocorrência de alterações audiológicas, assim como de acompanhamento audiológico dos neonatos com hiperbilirrubinemia.

PALAVRAS-CHAVE: Hiperbilirrubinemia. Recém-nascido. Icterícia. Perda auditiva.

\section{REFERENCES}

1. Olds C, Oghalai S. Audiologic impairment associated with bilirubin-induced neurologic damage. Semin Fetal Neonatal Med. 2015;20(1):42-6.

2. Corujo-Santana C, Falcón-González IC, Borkoski-Barreiro SA, Pérez-Plasencia D, Ramos-Macías Á. The relationship between neonatal hyperbilirubinemia and sensorineural hearing loss. Acta Otorrinolaringol Esp. 2015;66(6):326-31.

3. Okhravi T, Tarvij Eslami S, Hushyar Ahmadi A, Nassirian H, Najibpour R. Evaluation of auditory brain stems evoked response in newborns with pathologic hyperbilirubinemia in Mashhad, Iran. Iran Red Crescent Med J. 2015;17(2):e18288.

4. Panahi R, Jafari Z, Sheibanizade A, Salehi M, Esteghamati A, Hasani S. The Relationship between the behavioral hearing thresholds and maximum bilirubin levels at birth in children with a history of neonatal hyperbilirubinemia. Iran J Otorhinolaryngol. 2013;25(72):127-34.

5. Peyvandi AA, Eftekharian A, Goljanian A, Alani N. The relationship between severe hyperbilirubinemia and abnormal Auditory Brainstem Response in children. Int J Pediatr. 2014;2(3.3):5-10.

6. Akinpelu OV, Waissbluth S, Daniel S). Auditory risk of hyperbilirubinemia in term newborns: a systematic review. Int J Pediatr Otorhinolaryngol. 2013;77(6):898-905.

7. jiang $Z D$, Wilkinson $A R$. Impaired function of the auditory brainstem in term neonates with hyperbilirubinemia. Brain Dev. 2014;36(3):212-8.
8. Martínez-Cruz CF, García Alonso-Themann P, Poblano A, Cedillo-Rodríguez IA. Hearing and neurological impairment in children with history of exchange transfusion for neonatal hyperbilirubinemia. Int J Pediatr. 2014;2014:605828

9. Hulzebos CV, van Dommelen P, Verkerk PH, Dijk PH, Van Straaten HL. Evaluation of treatment thresholds for unconjugated hyperbilirubinemia in preterm infants: effects on serum bilirubin and on hearing loss? PLoS One. 2013;8(5):e62858.

10. Higgins JPT, Green S. Cochrane handbook for systematic reviews of interventions Version 5.1.0. The Cochrane Collaboration, 2011. [cited 2019 Sep 6]. Available from: https://training.cochrane.org/handbook/current

11. Oxford Centre for Evidence-Based Medicine. Oxford Centre for Evidence-Based Medicine 2011 levels of evidence. [cited 2019 Sep 6]. Available from: https://www.cebm.net/wp-content/uploads/2014/06/ CEBM-Levels-of-Evidence-2.1.pdf

12. Public Health Resource Unit, The University of Kent, Critical Appraisal of the Journal Literature. Critical Appraisal Skills Programme (CASP). Evaluation tool for quantitative studies. Oxford: Public Health Resource Unit; 2006.

13. Agrawal VK, Shukla R, Misra PK, Kapoor RK, Malik GK. Brainstem auditory evoked response in newborns with hyperbilirubinemia. Indian Pediatr. 1998;35(6):513-8. 
14. Bhandari V, Narang A, Mann SB, Raghunathan M, Bhakoo ON. Brain stem electric response audiometry in neonates with hyperbilirubinemia. Indian Pediatr. 1993;60(3):409-13.

15. Gupta AK, Raj H, Anand NK. Auditory brainstem responses (ABR) in neonates with hyperbilirubinemia. Indian | Pediatr. 1990;57(5):705-11.

16. Martiñón RT, Salazar GV, Román IG, Carranza RA, liménez CU, Coron MAC, et al. Emisiones otoacústicas y potenciales auditivos de tallo cerebral en hiperbilirrubinemia neonatal. An Otorrinolaringol Mex. 2000;45(2):51-6.

17. Tan KL, Skurr BA, Yip YY. Phototherapy and the brain-stem auditory evoked response in neonatal hyperbilirubinemia. J Pediatr. 1992;120(2 Pt 1):306-8.

18. Chapchap MJ, Segre CAM. Auditory brainstem responses in term newborns with hyperbilirubinemia. Einstein. 2006;4(3):179-86.
19. Baradaranfar $\mathrm{MH}$, Atighechi $\mathrm{S}$, Dadgarnia $\mathrm{MH}$, Jafari $\mathrm{R}$, Karimi $\mathrm{G}$, Mollasadeghi $A$, et al. Hearing status in neonatal hyperbilirubinemia by auditory brain stem evoked response and transient evoked otoacoustic emission. Acta Med Iran. 2011;49(2):109-12.

20. Brasil. Ministério da Saúde. Diretrizes de atenção da triagem auditiva neonatal. Brasília: Ministério da Saúde; 2012. [acesso em 2019 Sep 21]. Available from: https://bvsms.saude.gov.br/bvs/publicacoes/diretrizes_atencao_triagem_auditiva_neonatal.pdf

21. Saluja S, Agarwal A, Kler N, Amin S. Auditory neuropathy spectrum disorder in late preterm and term infants with severe jaundice. Int J Pediatr Otorhinolaryngol. 2010;74(11):1292-7.

22. American Academy of Pediatrics, Joint Committee on Infant Hearing. Year 2007 position statement: principles and guidelines for early hearing detection and intervention programs. Pediatrics. 2007;120(4):898-921. 